\title{
Relational Direction Model (RDM) of E-Retailing Developed during Research on Direction of Online Retailing (In the Context of United Arab Emirates)
}

\author{
Ashok Chopra ${ }^{1}$ \\ ${ }^{1}$ Faculty of Management Studies Banasthali Vidyapith, Rajasthan, India \\ Correspondence: Ashok Chopra, Faculty of Management Studies Banasthali Vidyapith, Rajasthan, India. E-mail: \\ ashok@ideaforlife.ae
}

Received: July 10, 2016 Accepted: July 25, 2016 Online Published: July 29, 2016

doi:10.5539/ijms.v8n4p124 URL: http://dx.doi.org/10.5539/ijms.v8n4p124

\begin{abstract}
Global revenues in 2013 from online retail sales have crossed the \$1Trillion barrier, getting an extra push from the expected jump in Internet user numbers. The primary objective of this research is to generally examine and analyze the scope and future of online retailing in UAE. In order to get more accurate results, the main objective of this research was divided into very specific contexts which all explored the concept of online retailing in UAE at the final point. One particular aspect to examine is to find out the current attitude of the UAE population towards online shopping based on UAE web stores. And further look into what commonly motivates the customers to go online and buy their preferred items instead of going to a physical shop. Final aim of this study is to discover how a typical online retailer performs in UAE, in terms of security, costs, and product offerings.

This study is an exploratory in nature, and both primary and secondary data is deployed. Secondary data is collected from one hundred thirty academic journals (e-journals) from different parts of the world and text books studied from literature review perspective; The Primary data is collected by executing an online survey served through questionnaire (questions resulted from factors and variables collected through studying e-journals).
\end{abstract}

Keywords: Relational Direction Model, E-Retailing

\section{Introduction}

Online retailing is considered as one of the fastest growing retailing forms taking convenience to an entire new level where a shopper can make a purchase from anywhere at any time, regardless to the nature of the product and the distance from the marketer or supplier. Online shopping is the process whereby consumers directly buy goods or services from a seller in real-time, without an intermediary service, over the internet. An online shop, e-shop, e-store, internet shop, web shop, web-store, online store, or virtual store; are a few common names synonym to online formats of shopping. These days online retailing is attracting heavily customers throughout the world. In many countries companies like Dell Computers, Amazon.com, flicker, Dubizzle souq.com, myntra and e-bay have already established a remarkable success and worldwide popularity. With the invention of new and advanced technology of Internet, many retailers have now moved towards the online retailing. Many of the retailers who perform their businesses primarily through physical stores, in addition have now added, this new format of online retailing in their operations. For example, Samsung, Apple, Carrefour, Geant and many more companies now, serve their customers through both the modes i.e. the physical stores and online stores.

Online retailing has already developed and gained huge acceptance in both developed and developing world countries. However, it is still in the evolving phase in many underdeveloped and emerging market countries.

Dubai, (United Arab Emirates) which is mainly famous as a tourist destination and is largely considered as a shopping paradise in the whole Middle East, offers customers/visitors a wide variety of retail outlets. The retail outlets are mainly located within mega shopping malls and huge hyper markets; but the culture of online retailing is yet at its infancy. Some of the examples of online retailers in UAE are souq.com, dubizzle.com, boutique1.com, ellamart.com, brownbag.ae, emiratesavenue.com and nahel.co. The proposed study is aimed with the basic objective of knowing the shopper's attitude towards online retailing and what are the future prospects of this retail format in UAE. 


\subsection{About E-Retailing in UAE}

Overall, the retail market in UAE has grown spectacularly over the past five years, with total sales up 50 per cent to US\$19.75 billion (Dh72.54bn), according to Euromonitor, a data provider. But experts are now divided on whether the sector is booming or merely spluttering along, with many retailers claiming to be experiencing "the best of times", while other stores are much less buoyant.

Euromonitor predicts UAE retail sales to grow just 1 per cent this year (2013), someway, below the Ministry of Economy's GDP predictions of three per cent. "Within retailing, different channels are performing differently, with supermarkets and hypermarkets registering healthy growth, while channels such as jewelers and independent small grocers are faring badly and registering negative growth," said Sana Toukan, the research manager for Euromonitor in the Middle East.

One of the UAE's biggest retail executives has described online shopping as "boring" and doesn't believe, it can ever replace physical stores. Mohi-din BinHendi, president of BinHendi Enterprises, which is the partner for seventy-five brands in the UAE, says online shopping will never be a big market for the "Jet-Set" of luxury shoppers. "You do not interact with anybody but only a screen and your fingertips. In malls you walk around, mingle with people and feel the products," said Mr BinHendi at the InRetail Summit held in Dubai.

"Shopping for luxury goods, clothes and jewelry, I do not think it can ever happen through net and that online can ever take away this pleasure from shoppers. Online shopping can never replace what we have today," he added. But many executives disagree with Mr BinHendi's assessment and believe online shopping is rapidly set to become popular among consumers in UAE as well in other Middle East countries.

"Every retailer needs to think about online," said Nisreen Shocair, the president of Virgin Middle East and North Africa. "I do not think it is an option, it is a matter of when."

Virgin continues to invest in expanding its physical stores, but also plans to launch an online digital music download before the end of the year. Price and convenience are the two factors driving shoppers online as consumers increasingly value time saved. Shocair said. "If there are some brands that have not given [retailers] the option to go online, then this is the next conversation to be had," she added.

JPMorgan forecasts global e-commerce revenues to grow dramatically this year, up 18.9 per cent to US\$680 billion (Dh2.49 trillion) compared to last year.

But e-commerce has been slow to take off in the Middle East where just 6 per cent internet users regularly shop online, according to a recent survey by the Dubai market research company Real Opinions.

Simon Marshall, chief executive of Fawaz Alhokair, a Saudi-based retailer with more than one thousand physical stores around the Middle East, forecasts online sales to make up 20 to 25 per cent of total sales within next five years. "Online is a massive opportunity. It's significant for us," he said.

Above are the views of some veterans of UAE and Middle East retailers, who clearly are divided on the issue on online retailing.

\subsection{Research Objective}

The primary objective of this research paper is to generally examine and analyze the scope and future of online retailing in UAE. In order to get more accurate results, the main objective of this research was divided into very specific contexts which all explored the concept of online retailing in UAE, at the final point. One particular concept to examine was to find out the current attitude of the UAE population towards online shopping on UAE based web stores.

Furthermore, it is vital to identify what UAE population look to buy in general and specify which category of products they prefer buying online.

The other area to look at was to find out what commonly motivated the customers to go online and buy their preferred items instead of going to a physical shop. Finally, to discover how a typical online retailer would perform in UAE in terms of security, costs, product offerings, and attracting customers.

The last stage included an analysis of the information and findings, hence a more in depth look at the whole issue of E-Retailing in UAE. The, conclusion has drawn the sight in the future of online retailing in the UAE and how to succeed in this particular field.

To summarize, the study targeted:

(i) To evaluate attitude of various types of customers towards online retailing. 
(ii) To examine the direction adopted by shoppers towards online shopping; with special reference to UAE.

(iii) To analyze the future of online retailing in UAE.

(iv) To design conceptual framework towards finding variables responsible for online retailing and physical retailing, and validating important variables to factors for designing model.

(v) To bring out suggestive recommendations if any towards positive development of agencies responsible for online retailing.

\subsection{Statement of Hypotheses}

(i) There is no difference in awareness of male and female customers about online shopping (Ho1).

(ii) There is no difference in key problems encountered by of male and female customers about online shopping (Ho2).

(iii) Online shopping behaviour is not independent of age of customers (Ho3).

\section{Methodology}

This study is an exploratory in nature, and both primary and secondary data is deployed in the study. Secondary data is collected from one hundred twenty five academic journals, e-journals from different parts of the world which included USA, Malaysia, Singapore, UK, China, India, Taiwan, Canada, France, Denmark, UK, England, New Zealand, Belgium, South Korea, Spain, Hong Kong, Italy, Greece, Croatia, Thailand, Israel, Finland, Saudi Arabia, Germany, Kuwait, Netherland and many more countries and text books for literature review, whereas Primary data is collected by executing an online survey and personal interviews from 460 respondents on the topic. Judgmental approach of sampling was used in the study and respondents were selected by using convenience and judgment sampling methods. Collected data was analyzed by using appropriate statistical methods. Frequency distribution tables and pie charts and bar diagrams were used to present and compare the findings and interpreting the results.

UAE has been selected for the research population and the type of samples and the number of questions were determined on the basis of meeting the information requirements for the research. Although the selected samples were limited to people living in UAE region, and it was assumed that the samples from UAE might have represented the whole situation of online retailing in GCC. Therefore, the research results might be generalized to all GCC countries but strictly speaking, this generalization is limited.

This research rarely falls neatly into only one philosophical domain. This research too is mixture between positivist and interpretivist, perhaps reflecting the stance of realism. The logic of this research employed inductive as well as deductive (or dialectic) processes. The first part of the research is deductive in nature — variables/indicators/drivers/barriers are identified through literature review, framework is designed using pilot study, and framework is refined by questionnaire. The remaining part of the research is inductive - the refined framework is applied to real establishment and analysis is done to refine the framework.

"A pilot study has provided an opportunity to test out some of the research objectives thus enabled the research to make necessary changes or amendments before the primary data was collected. Pilot study interview questionnaire instrument has been created on basis of literature review and discussion. This survey instrument has been used to elicit information from a sample set of people and practitioners. The information collected then had been analyzed qualitatively and was used for creation of framework. This framework was then used in the research development phase."

The research activities included data collection though semi-structured interviews, traditional questionnaire, web questionnaire, pilot study, expert opinion study, case study methods etc. This phase also included quantitative analysis of data and refining the framework created in the planning phase. The refined Framework was then used in the research validation phase.

The final phase of the research is the validation phase and its objective was to validate the research findings. The data collected by this method has been analyzed and the final findings were critically examined to draw conclusions and future research recommendations.

\subsection{Methodology for Undertaken Research}

UAE has been selected for the research population and the type of samples and the number of respondents were determined on the basis of meeting the information requirements for the research. Pilot questionnaire was administered by way of structured questionnaires in person to forty respondents to find out suitability of questions and overall structure of the questionnaire and it was found the pilot questionnaire was appropriate to be 
served to main respondents. A pilot study provided an opportunity to test out some of the research objectives thus enabled the researcher to make necessary changes or amendments before the primary data was collected. Pilot study interview questionnaire instrument was created on basis of literature review and discussion.

Questionnaire was served to one thousand five hundred people through mail using Google formsas main basis. Five hundred twenty-five people responded. After cleaning was performed exact four hundred sixty clean responses were considered. Respondents included working professionals, households, students and UAE population at large whose minimum qualification was under graduate. However, qualification mix of respondents included graduates, post graduates, professional degree holders and $\mathrm{PhD}$ scholars.

\section{Results}

\subsection{Cronbach Alpha Reliability Factor Analysis}

After the analysis of mean, standard deviation and variance, the factor analysis was applied on data collected. The objective of applying factor analysis was to collapse large number of variables into few interpretable underlying factors. In E-Retailing there are number of variables which are having similar pattern of responses because they are all associated with latent variable. Each factor records certain amount of overall variance in the observed variables and the factors are always listed in order of how much variation they explain.

Table 1 gives complete view of factors and associated variables along with value of alpha. The factors have been named in such a manner that they can represent the variables associated with a factor. There were total thirty-six descriptive factors on which Cronbach Alpha Factor analysis was applied. Of these thirty-five factors gave nine cohesive factors and one factor was left out as single factor did not have another factor to form the group.

Table 1. Cronbach alpha factor analysis

\begin{tabular}{|c|c|c|c|}
\hline S.No. & Factor & Variable & Cronbach's Alpha (Reliability Factor) \\
\hline 1 & E-Retailing Enablers (EE) & Variety & 0.71 \\
\hline 2 & & Convenience & \\
\hline 3 & & Saves time & \\
\hline 4 & & Seeking product price info. and comparison & \\
\hline 5 & E-Retailing Governors (EG) & $\begin{array}{l}\text { Characteristics / technical complexity of the goods } \\
\text { to be purchased. }\end{array}$ & 0.69 \\
\hline 6 & & Website characteristics & \\
\hline 7 & & Guaranteed money refund & \\
\hline 8 & & More internet usage & \\
\hline 9 & & Mall preference & \\
\hline 10 & & Special promotional offers & \\
\hline 11 & E-Retailing Boosters (EB) & Personal satisfaction & 0.72 \\
\hline 12 & & Utilitarian shopping values & \\
\hline 13 & & Perceived usefulness & \\
\hline 14 & & Good transaction services & \\
\hline 15 & & Internet self efficacy & \\
\hline 16 & E-Retailing Aiders (EA) & Peer/colleague recommendation & 0.66 \\
\hline 17 & & New trend of downloadable mobile apps & \\
\hline 18 & & Enjoyment in earlier dollar amount spent & \\
\hline 19 & & Strict complaint addressing system & \\
\hline 20 & E-Retailing Traitors (ET) & Higher ego related needs & 0.60 \\
\hline 21 & & Negative word of mouth & \\
\hline 22 & & Social pressure & \\
\hline 23 & E-Retailing Modernizers (EM) & Burst of social networking & 0.61 \\
\hline 24 & & Multimedia S/W & \\
\hline 25 & & Post purchase experiences & \\
\hline 26 & & Store/brand loyalty & \\
\hline 27 & E-Retailing Impactors (EI) & $\begin{array}{l}\text { Online shopping is independent of reputed online } \\
\text { retailer brands/product authorized retailer websites. }\end{array}$ & 0.60 \\
\hline 28 & & International rating of online shopping site & \\
\hline 29 & & Expert/celebrity endorsements of online shopping & \\
\hline 30 & E-Retailing Limiters (EL) & Per capita income $\&$ shopping online & 0.61 \\
\hline 31 & & Concept of mega malls & \\
\hline 32 & & Source of revenue and employment generation & \\
\hline 33 & & To seek better margin, organization & \\
\hline 34 & E-Retailing Discretors (ED) & Privacy concern & 0.35 \\
\hline 35 & & $\begin{array}{l}\text { Living alone, facing loneliness \& to have perceived } \\
\text { Social support }\end{array}$ & \\
\hline
\end{tabular}


Of these thirty-five factors first set of four variables were grouped together with Alpha value of 0.71 . The nomenclature given to first group was E-Retailing Enablers (EE) as these variables make shoppers enable E-Retailing.

The second set of seven variables (one variable with lower value of 0.415 of strict complaint addressing system was left out to be grouped with more relevant set of variable, so effectively six variables) grouped together as factor and was nomenclature as E-Retailing Governors (EG). This set included variables namely characteristics / technical complexity of the goods to be purchased, website characteristics, guaranteed money refund, more internet usage, mall preference, special promotional offer with alpha value of 0.69 . Looking at variables it is believed that these variables really govern the E-Retailing and oversee and regulate them, that is without these set of variables E-Retailing may lose focus on shoppers.

The third set of factor comprised of five variables namely personal satisfaction, utilitarian shopping values, perceived usefulness, good transaction services, internet self efficacy with alpha value of 0.72 (highest among all variables) wasnomenclature as E-Retailing Booster (EB). Looking at variables it shows these set of variables really enhance and lift the mood of shoppers towards E-Retailing.

The fourth set consisted of five variables (one variable with lower value of 0.415 which is mall preference leads to physical retailing was left out to be grouped with more relevant set of variable), so effectively four variables grouped together as peer/colleague recommendation, new trend of downloadable mobile apps, enjoyment in earlier dollar amount spent, strict complaint addressing system with alpha value of 0.66 was nomenclature as E-Retailing Aider (EA). These variables really support the shoppers for E-Retailing.

The fifth set consisted of three variables namely Higher Ego related needs, negative word of mouth, social pressure with alpha value of 0.60 were nomenclature as E-Retailing Traitors (ET). These variables actually act as conspirator and support physical retailing. These set of variables collaborate more with Brick and Mortar shopping. These variables are dominant in UAE.

The sixth set consisted of four variables namely burst of social networking, multimedia $\mathrm{S} / \mathrm{W}$, post purchase experiences, store/brand loyalty with alpha value of 0.61 were nomenclature as E-Retailing Modernizers (EM). Out of these burst of social networking sites and multimedia S/W, (that makes product demonstration, attributes \& characteristics look better) encourage and helping spread E-Retailing for non E-Retail buyers in place like UAE. And store/brand loyalty along with post purchase experience does help shoppers towards Brick and Mortar shopping. But it is felt that these variables in today's scenario are losing importance as physical retailing is becoming more of two days (weekend days and holidays) week shopping.

The seventh set consisted of four variables namely online shopping is independent of reputed online retailer brands/product authorized retailer websites, international rating of online shopping site, expert/celebrity endorsements of online shopping, (one variable with lower value of 0.411 which is majority of expatriates, who live alone and face loneliness \& perceived social support are more likely to use internet and shop online was left out to be grouped with more relevant set of variables, so effectively four variables) with alpha value of 0.60 was nomenclature as E-Retailing Impactors EI). These variables indeed are making difference in today's scenarios. More and more of E-Retailers use celebrity endorsement to encourage shoppers for E-Retailing. Shoppers mainly do not look for brand's/Company's websites rather visit popular E-Retailing websites to choose preferred brands.

The eighth set consisted of four variables namely per capita income \& shopping online, concept of mega malls, source of revenue and employment generation, to seek better margin, organizations are encouraged to physically retail their specific higher margin model themselves rather through E-Retailing with alpha value of 0.61 were nomenclature as E-Retailing Limiters (EL). These variables indeed are restrainers on E-Retailing and supporting Brick and Mortar shopping. These variables have been well exploited by physical retailers, companies for seeking better margins for certain models of their product lines and governments to boost income levels for inhabitants.

The ninth set consisted of three variables namely privacy concern is one of the reasons to go for online shopping (products you may not like to buy in public), majority of expatriates, who live alone and face loneliness \& perceived social support are more likely to use internet and shop online (one variable store/brand loyalty leads to physical shopping with lower value of 0.424 has already been aligned with more relevant set of variables) with alpha value of 0.35 were nomenclature as E-Retailing Discretors (ED). These variables really did not make much impact on E-Retailing and were mainly detached from all other variables.

The last variable which was left alone was Online shopping is virtue for old age people/physically 
challenged/Special Need people provided online shopping is easy and safe. This variable couldn't be aligned with any other variables because of security and safety concern attribute for referred set of shoppers.

\subsubsection{E-Retailing Enablers (EE)}

The first Factor has been named as E-Retailing Enablers (EE), which has variables like variety, convenienence, saves time and seeking product price information and comparison. The high score of 0.71 shows high reliability and low error rate of 0.49 . The score also confirms that the variables are unidimensional pointing out that in today's time where people lead a busy lifestyle. A factor like E-Retailing Enablers (convenience, time saving, variety at one place sitting inside your home and seeking product information) not only makes shopping comfortable rather adds value to it too. The E-Retailers should always incorporate these factors while planning their retailing.

\subsubsection{E-Retailing Governors (EG)}

The second factor has been named as E-Retailing Governors (EG) and it has variables like characteristics / technical complexity of the goods to be purchased, website characteristics, guaranteed money refund, more internet usage, mall preference, special promotional offer with alpha value of 0.69 and error score of 0.52 . Actually looking at variables carefully it would be noticed that there is continuous struggle and fight among variables to shift shoppers between E-Retailing and Brick and Mortar shopping. These variables indeed govern the shoppers from shifting to either mode of shopping.

\subsubsection{E-Retailing Boosters (EB)}

The third factor has been named as E-Retailing Booster (EB) and it has variables like personal satisfaction, utilitarian shopping values, perceived usefulness, good transaction services, and internet self efficacy with alpha value of 0.72 (highest among all factors) and error score of 0.42 . The variables covered are real supporter of E-Retailing and has impacted E-Retailing for decades. The fact is further supported by higher value which shows uni-dimensionality among variable as unique factor.

\subsubsection{E-Retailing Aiders (EA)}

The fourth factor has been named as E-Retailing Aiders (EA) and it has variables like peer/colleague recommendation, new trend of downloadable mobile apps, enjoyment in earlier dollar amount spent, and strict complaint addressing system with alpha value of 0.66 and error score of 0.56 . Out these variables new trends like down loadable mobile apps have revolutionized the E-Retailing. In UAE though these apps are more used for the purpose of E-Commerce rather than E-Retailing which clearly shows these apps are making revolution but government is making more usage in constructive way than public. Though there is no single body at country level except people are still reporting complaints to Cyber Police, who cautions people. General awareness and social advertising can help to an extent to prevent people from getting into clutches of such fake E-Retailers. But all the variables in this factor segment are encouraging.

\subsubsection{E-Retailing Traitors (ET)}

The fifth factor has been named as E-Retailing Traitors (ET) and it has variables like higher ego related needs, negative word of mouth, and social pressure with alpha value of 0.60 and error value of 0.64 . Though the alpha value is not very high this factor in UAE context has lot of importance. The variables like higher ego related need, social pressure and negative word of mouth do play important role and encouragement for customers to go for Brick and Mortar Shopping. Researcher feels just border line value of alpha is due to lower number of locals as respondents. Close look at variables would point that these variables are really are defectors and deserters of E-Shopping.

\subsubsection{E-Retailing Modernizers (EM)}

The sixth factor has been named as E-Retailing Modernizers (EM) and it has variables like burst of social networking, multimedia s/w, post purchase experiences and store/brand loyalty with alpha value of 0.61 and error factor of 0.62 . If E-Retailers need to attract and retain satisfied online shoppers, they need to know what evaluative criteria consumers use when selecting an E-Retailer. Four main e-shopping characteristics are merchandise, interactivity - the customer support and service that customers can receive from the internet, just as they can from a salesperson in a brick and mortar store, reliability - an E-Retailer's good reputation, plus security and privacy navigation characteristics - the time taken to get to an E-Retailer's homepage, and to download the E-Retailer's Web pages. Undoubtedly variables under these factors are reformers and trendsetters for E-Retailing. 


\subsubsection{E-Retailing Impactors (EI)}

The seventh factor has been named E-Retailing Impactors (EI) and it has variables like online shopping is independent of reputed online retailer brands/product authorized retailer websites, international rating of online shopping site, expert/celebrity endorsements of online shopping, with alpha value of 0.60 and error value of 0.64 These variables indeed are making difference in today's scenarios. More and more of E-Retailers use celebrity endorsement to encourage shoppers for E-Retailing. Shoppers mainly do not look for brand's/company's websites rather visit popular E-Retailing websites to choose preferred brands.

\subsubsection{E-Retailing Limiters (EL)}

The eighth factor has been named as E-Retailing Limiters (EL) and it has variables like there is correlation between per capita income \& shopping online, concept of mega malls (which have multiple high end retail channels catering lifestyle of local society, attractiveness of malls, shopping incentive) discourages online Retailing, In UAE (specially Dubai)'s focus is on physical retailing (as it being a major source of revenue and employment generation) and to seek better margin, organizations are encouraged to physically retail their specific higher margin model themselves rather through E-Retailing with Alpha value of 0.61 and error factor of 0.62. In UAE since Tourism is focus area of government so malls with multiplexes such as cinema theatres, food courts, play places for children are becoming the center for family outings specially for tourist. Demographic profile variables correlate significantly with perceived risk and intention to adopt an online retailer. Specifically, if a consumer has higher income, higher education and he/she (or his/her core family) owns a home, he/she tends to perceive less risk in online shopping and to have a higher intention to adopt an online retailer; in UAE in the absence of these, online shopping tends to be low. Revenue is important to Government as they high obligation towards national income thus Brick and Mortar shopping is boosted as it makes huge source of Government and national income as rent. Keeping above in mind researcher feels variables mentioned in this factor are real limiters of online shopping.

\subsubsection{E-Retailing Discretors (ED)}

This factor consisted of three variables namely privacy concern is one of the reasons to go for online shopping (products you may not like to buy in public), majority of expatriates, who live alone and face loneliness \& perceived social support are more likely to use internet and shop online (one variable store/brand loyalty leads to physical shopping with lower value of 0.424 has already been aligned with more relevant set of variables) with alpha value of 0.35 were nomenclature as E-Retailing Discretors (ED). These variables really did not make much impact on E-Retailing and were mainly detached from all other variables.

\subsection{Shaping the Relations Direction Model (RDM) of E-Retailing}

The factors and the variables on the basis of which primary data was collected and analyzed were further grouped to form ten broad factors. Out of these broad factors one factor had only one variable thus was left out and researcher was left with nine broad factors. These factors were further analyzed with their respective set of variables and were nomenclature with best suited names. From these a relational direction of model of E-Retailing was developed. 


\subsubsection{E-Retailing Enablers (EE)}

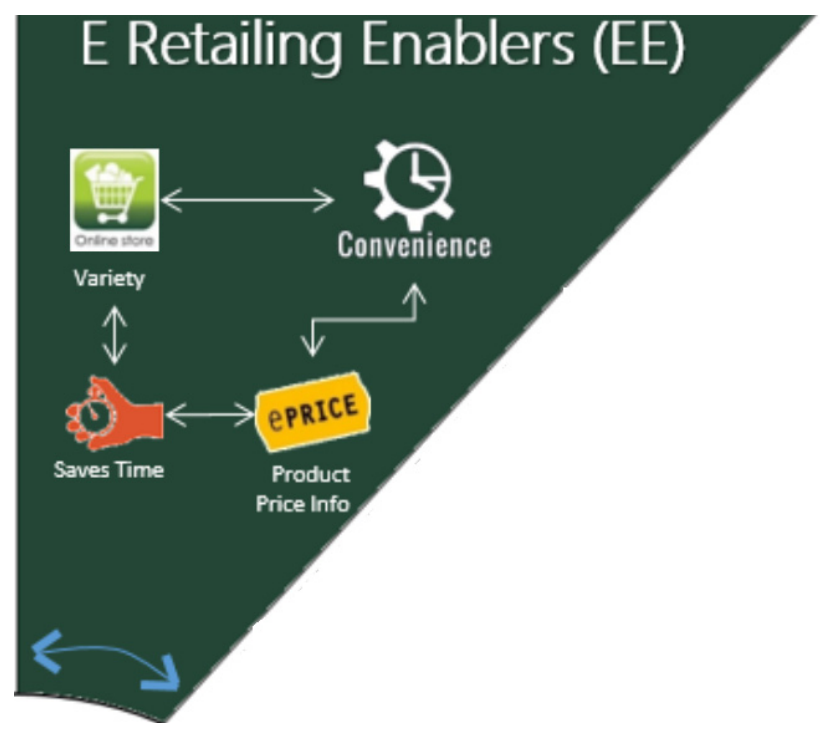

Figure 1. E-Retailing Enablers (EE)

Table 2. Statistics of factor E-Retailing Enablers (EE)

\begin{tabular}{lllllllll}
\hline E-Retailing Enablers (EE): & \multicolumn{10}{c}{ (E) } & Range & Minimum & Maximum & Sum & Mean & Std. Deviation & Variance \\
\hline Online shopping is convenient & 460 & 4 & 1 & 5 & 1785 & 3.88 & .908 & .824 \\
Online shopping has variety & 460 & 4 & 1 & 5 & 1818 & 3.95 & .911 & .830 \\
Online shopping saves time & 460 & 4 & 1 & 5 & $\mathbf{1 9 2 2}$ & 4.18 & .847 & .718 \\
Before buying physically one often & 460 & 4 & 1 & 5 & 1866 & 4.06 & .929 & .864 \\
\hline
\end{tabular}

E-Retailing Enablers(EE) are led by variable online shopping saves time, followed by before buying physically one often visits various E-shopping sites for seeking product price information, and product comparison which in turn saves time, even one is buying offline (Brick \& Mortar). Experiential features need to be implemented in a way that does not interfere, with the goal-directed orientation of most online buyers (Gilly \& Wolfinbarger, 2000). Product involvement can influence consumer acceptance of online shopping, but their influence varies according to product types (Lian \& Lin, 2007). The physical retailing requires more space incase retailer wants to offer variety which needs bigger store, thus more rent which in turn makes price of product higher. Whereas, in E-Retailing huge variety can be offered by having higher disc storage capacity which is easy to maintain and rather less inexpensive as compared to physical retail storage. Internet shopping mall consider the Website not merely as an information system but also as a virtual store which provides the full stages of purchasing process of finding, ordering, and receiving. The dual nature of the online consumer as a tradition shopper and a Web user implies that the offline features are just as important to retain customers as online quality factors (Ahn, Ryu, \& Han, 2004). Convenience is biggest asset of E-Retailing. Saving time, avoiding traffic, finding parking all consumes time which is precious in today life style, so online shoppers seek convenience, which is also confirmed by Internet shoppers are more convenience seekers, innovative, impulsive, variety seekers, and less risk averse than Internet non-shoppers are. Internet shoppers are also less brand and price conscious than Internet non-shoppers are. Internet shoppers have a more positive attitude toward advertising and direct marketing than non-shoppers do (Naveen Donthu Georgia State University Adriana Garcia United Parcel Service, 1999). So saving time, seeking variety, having convenience and comparison before buying for ease and avoiding hustles are led by E-Retailing Factor of E-Retailing Enablers (EE). Low price, better quality, and availability of a variety of routes to shopping also influence shoppers' behavior in urban markets. Hence, shopping malls and large retailers located in malls should strive to achieve operating efficiencies by making malls attractive, lowering prices, and opening multichannel retailing options to customers. Such strategies would enable retailing firms to sustain increasing competition and gain a larger market share (Rajagopal, 2005-2008). 


\subsubsection{E-Retailing Governors (EG)}

The next factor is E-Retailing Governors (EG) and it has variables like characteristics / technical complexity of the goods to be purchased, website characteristics (like design, multiple contact points alternative ordering, good product search \& comparison matrix, the number of monthly \& quarterly changes, and accessibility from other web pages) encourages buying online, guaranteed money refund on return of purchased product impacts online shopping positively. More internet usage, Mall preference, Special Promotional Offer lead to physical shopping is led by variable Special Promotional Offers leads to physical shopping followed by website characteristics encourages buying online.

The E-Retailing Governors were given nomenclature as all the variables are impacting each other and buyers who are confused between online and physical retailing specially in place like United Arab Emirates where physical retailing is more prevalent because of government focus on hospitality, retail and trading. Consumers perceive Internet shopping to be of higher risk than in-store shopping; hence only less risk averse consumers are more likely to use Internet shopping services. The results confirm earlier findings that money-back guarantee is the most important risk reliever, followed by offering a well-known brand and a price reduction (Dirk Van den \& Leunis, 1999). The high importance placed on variable called consumer reference group appeals, as it is effective risk reliever, and further gives Internet marketers a great opportunity to incorporate reference group influences appeal in their advertising and promotional strategies in Internet marketing (Soo, 1999).

Table 3. Statistics of factor E-Retailing Governors (EG)

\begin{tabular}{lllllllll}
\hline E-Retailing Governors (EG): & \multicolumn{1}{l}{} \\
\hline Online shopping depends upon characteristics & $\mathrm{N}$ & Range & Minimum & Maximum & Sum & Mean & Std. Deviation & Variance \\
Guaranteed money refund & 460 & 4 & 1 & 5 & 1743 & 3.79 & .932 & .868 \\
Website characteristics like design & 460 & 4 & 1 & 5 & 1818 & 3.95 & 1.045 & 1.091 \\
Mall preference leads to physical & 460 & 4 & 1 & 5 & 1835 & 3.99 & .925 & .856 \\
Special promotional offers lead to physical shopping & 459 & 4 & 1 & 5 & 1769 & 3.85 & .954 & .911 \\
More internet usage would impact E-Shopping & 460 & 4 & 1 & 5 & $\mathbf{1 8 3 7}$ & 3.99 & .978 & .956 \\
\hline
\end{tabular}

However, Website characteristics (like design, multiple contact points alternative Ordering, good product search \& comparison matrix, the number of monthly \& quarterly changes, and accessibility from other web pages) can make little impact to those buyers who if try online would definitely appreciate how different, convenient and easy it is to shop online. Especially the tourist product corresponds to a complex purchase which involves the consumer and leads him/her to search for information before making a definite choice. The consumer tries to materialize the service he/she chooses and also tries to reassure himself/herself in order to justify his/her choice. $\mathrm{He} / \mathrm{she}$ refers to the product's prevailing characteristics and also to secondary information perceived during negotiation with professionals, and which are likely to influence the final purchasing decision (Legohérel, Fischer-Lokou, \& Guéguen, 2000). The variables presented in this factor are dominant in physical retail through features like demonstration, salesperson role, two ways communication etc. If e-tailers want to attract and retain satisfied online shoppers, they need to know what evaluative criteria consumers use when selecting an e-tailer. four main e-shopping characteristics are merchandise, interactivity - the customer support and service that customers can receive from the internet, just as they can from a salesperson in a brick and mortar store, reliability - an e-tailer's good reputation, plus security and privacy navigation characteristics - the time taken to get to an e-tailer's homepage, and to download the e-tailer's web pages (Lim \& Dubinsky, 2004). A continuous impact of these variables on each other and corresponding variables in physical retailing fraternity make this factor as governors. The effort of E-Retailers should be to make these variables as effective as possible so that shift can take place towards E-Retailing. Guaranteed money refund is crucial in attracting consumer on online shopping if he/she is not satisfied as this refund is available to them in physical retailing coupled with complaining system local authorities. So if a buyer is not satisfied with the transaction, the seller must consider whether to offer compensation, such as return or refund. Reputation is critical to reducing buyers' perception of risk, whether in offline or online transactions, but its influence on auction success and the winning bid may be reduced when many sellers have the same or better reputation (Shen, Chiou, \& Kuo, 2004). 


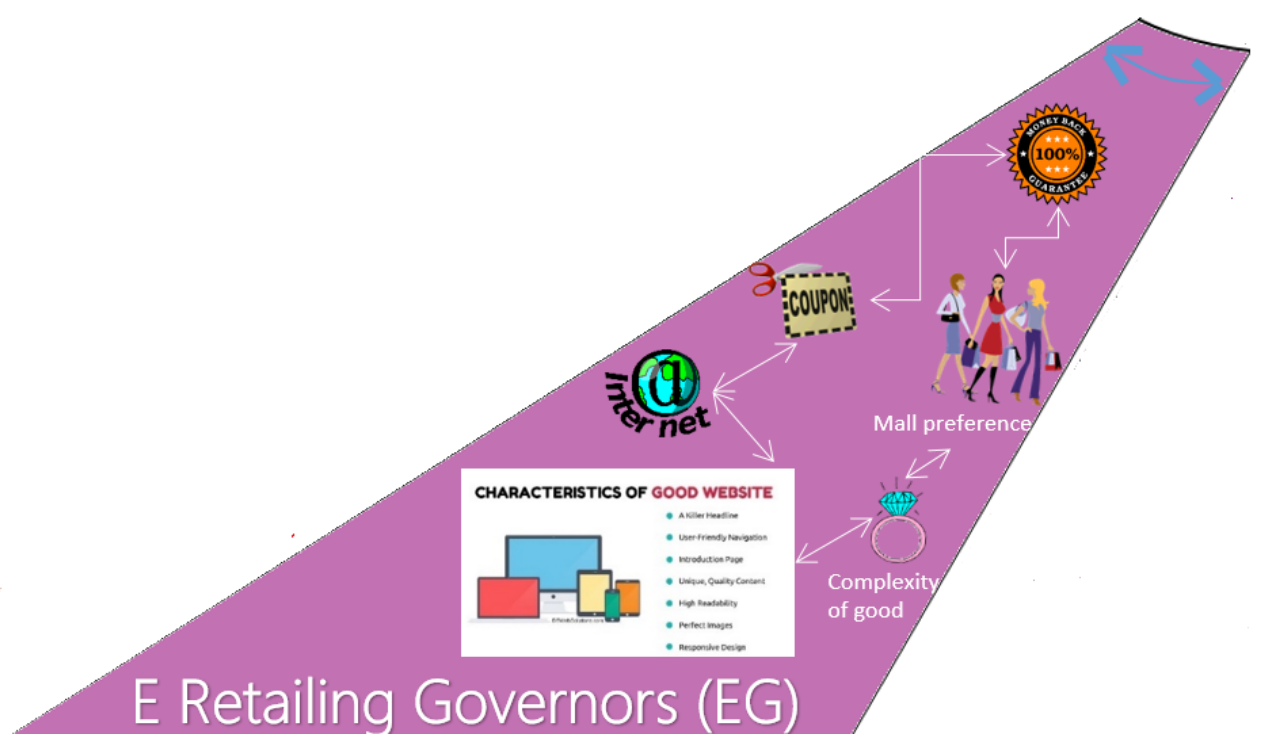

Figure 2. E-Retailing Governors (EG)

Malls are able to use integrated marketing communication and offer family outings by having multiplexes, kids play area, food courts etc. In contrast to above E-Retailers find it difficult to compete. Malls with multiplexes such as cinema theatres, food courts, play places for children are becoming the center for family outings. Small retailers have improved their service to cater to Indian consumers. Credit limits and home service are helping them to hold on to their customers. Retailing focus is changing towards satisfying the different hierarchy of needs of customers. Americans, arguably the biggest spenders in the world, have to make do with just about four shops per 1,000 populations. Singapore, the shoppers' paradise, has a similar density. England (rather, the UK), once scathingly referred to by Napoleon as a nation of shopkeepers is only marginally better it has nearly five shops for every 1,000 persons (Srivastava, 2008) We can find similar trend in UAE which is considered shopping heaven for GCC, Middle East \& MENA region. Four main e-shopping characteristics are Merchandise, Interactivity - the customer support and service that customers can receive from the Internet, just as they can from a salesperson in a brick and mortar store, Reliability - an e-retailer's good reputation, plus security and privacy Navigation characteristics - the time taken to get to an e-retailer's homepage, and to download the e-retailer's Web pages (Lim \& Dubinsky, 2004). Further thus, it is crucial that retailers provide such information to consumers prior to requiring them to place an item of interest in their shopping cart (Close \& Monika, 2009). The E-Retailing Governors (EG) effort should be encouraging customer to have more and more internet usage as it is researched that more internet usage leads to more online shopping. Internet usage and online shopping perception of convenience, which in turn influence their online shopping behaviors (Wu, Cai, \& Liu, 2005). Besides all other variables if incorporated to maximum extent for customer to experience these, would be good for E-Retailers to impact physical shopping buyers.

\subsubsection{E-Retailing Boosters (EB)}

This factor in the model is E-Retailing Boosters (EB) and it has variables like personal satisfaction leads to online shopping, utilitarian (useful/practical) shopping values leads to online shopping, online shoppers see perceived usefulness in E-Shopping. Good Transaction Services lead to Online Shopping (Transaction Services: security, product guarantees, safety of information, privacy, and delivery/customer service) and Internet Self Efficacy leads to Online Shopping. (Self- Efficacy: belief in one's capabilities to achieve a goal or an outcome)

The E-Retailing Boosters were given nomenclature as all variables in this factor pertain to usefulness of E-Shopping. The factor is led by variable Online shoppers see perceived usefulness in E-shopping, followed by Good Transaction Services lead to Online Shopping (Transaction Services: security, product guarantees, safety of information, privacy, and delivery/customer service) and others. E-Retailers in order to compete with physical shopping have to be boosting all variables so that shift can take place. Usefulness, ease of use and security were found to be significant predictors of attitude towards online shopping, but privacy was not. Further, intention to use on-line shopping was strongly influenced by attitude toward online shopping, normative beliefs, and self-efficacy (Vijayasarathy, 2002). 


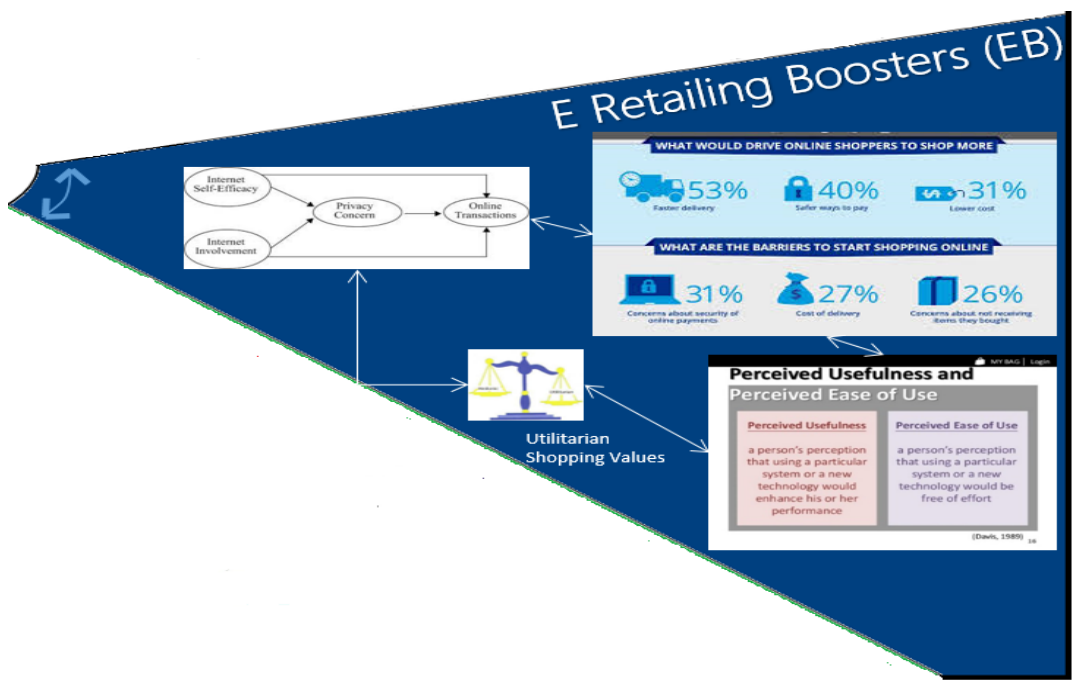

Figure 3. E-Retailing Boosters (EB)

E-Retailers in UAE and elsewhere have to ensure that while devising and making E-Retailing work effectively all the variables are well taken care. Researches have shown that intention to use the Internet to search for information was not only the strongest predictor of Internet purchase intention but also mediated relationships between purchasing intention and other predictors (i.e., attitude toward Internet shopping, perceived behavioral control, and previous Internet purchase experience). Direct and indirect relationships between two antecedents (attitude toward Internet shopping and previous Internet purchase experience) and Internet purchase intention were also found (Ha \& Stoel, 2008). Perceived ease of use and online shopping information dependency has a significant influence on shoppers' willingness to purchase online. Research shows that web content and design are key tools in the increase of future online purchasing. It is also recommended that managers target some of their advertising campaigns to the more innovative users (Enrique, Carla, Joaquín, \& Silvia, 2005). Perceived usefulness and perceived ease of use factors are valid predictors of behavioral intention. Perceived ease of use has positive direct effect on perceived usefulness.

Perceived usefulness and satisfaction influenced loyalty intention towards online shopping. Perceived ease of use acts indirectly on loyalty intention through the mediating effect of perceived usefulness. The development of self-efficacy judgments (e.g., enactive mastery, vicarious experience, verbal persuasion and physiological responses) would help to further validate the Internet self-efficacy scale presented in this study as well as increase our overall understanding of Internet use. There is consistent evidence of the construct validity of Internet self-efficacy. Internet self-efficacy was positively correlated to Internet usage, prior Internet experience, and outcome expectancies, as social cognitive theory suggests should be, and are negatively correlated with measures.Internet Self Efficacy should be inversely related to, Internet stress and self-disparagement. Internet self-efficacy was also unrelated to measures of general psychological well-being, including depression, loneliness, perceived social support and life stress, ruling out the competing hypothesis that self-efficacy merely reflects a generally positive outlook. (Eastin \& LaRose, 2000)

Table 4. Statistics of factor E-Retailing Boosters (EB)

\begin{tabular}{|c|c|c|c|c|c|c|c|c|}
\hline \multicolumn{9}{|l|}{ E-Retailing Boosters (EB): } \\
\hline & $\mathrm{N}$ & Range & Minimum & Maximum & Sum & Mean & Std. Deviation & Variance \\
\hline Internet self efficacy leads to online shopping & 460 & 4 & 1 & 5 & 1676 & 3.64 & .897 & .805 \\
\hline $\begin{array}{l}\text { Utilitarian useful practical shopping values leads to } \\
\text { online shopping }\end{array}$ & 460 & 4 & 1 & 5 & 1700 & 3.70 & .900 & .809 \\
\hline Personal satisfaction leads to online shopping & 460 & 4 & 1 & 5 & 1739 & 3.78 & .962 & .926 \\
\hline $\begin{array}{l}\text { Online shoppers see perceived usefulness in } \\
\text { E-Shopping }\end{array}$ & 460 & 4 & 1 & 5 & 1774 & 3.86 & .833 & .694 \\
\hline Good transaction services lead to online shopping & 460 & 4 & 1 & 5 & 1767 & 3.84 & .990 & .979 \\
\hline
\end{tabular}


In utilitarian shopping consumer's attitudes, expectations and preferences for interactive shopping may differ from those held in the physical retail shopping environment for identical products. Consumers may, in general expect to find more enjoyment in interactive environments than they do when shopping in physical environments. Service quality plays a significant role in increasing both utilitarian and hedonic shopping values. Research also shows that the impact of quality factors on Internet shopping values and subsequent repurchase intention is high.

All in all, E-Retailing boosters like perceived usefulness, good transaction services, personal satisfaction, utilitarian shopping values and self efficacy can make real difference when it comes to target switchers from physical to online shopping specially in country like UAE. Research also shows that intention to use the Internet to search for information was not only the strongest predictor of Internet purchase intention but also mediated relationships between purchasing intention and other predictors (i.e., attitude toward Internet shopping, perceived behavioral control, and previous Internet purchase experience) (Ha \& Stoel, 2008).

\subsubsection{E-Retailing Aiders (EA)}

E-Retailing Aiders (EA) has variables like Peer/colleague recommendation would encourage even a non-internet user to go for online shopping, New trend of downloadable mobile apps encourages people to shop online, Enjoyment in earlier Dollar amount spent on E-Shopping encourages E-Shopping, and Strict complaint addressing system for online purchases encourages E-Shopping.

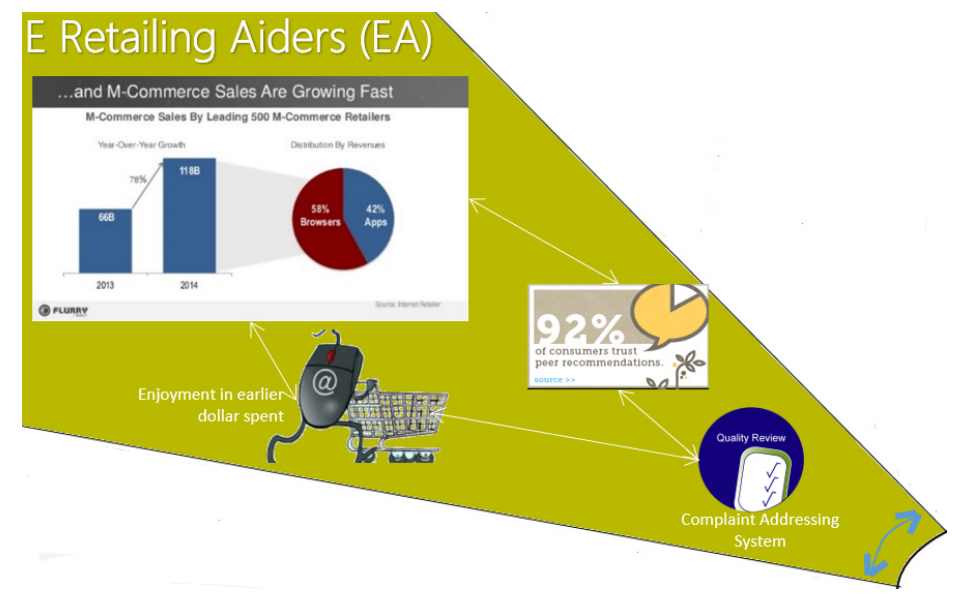

Figure 4. E-Retailing Aiders (EA)

The group is led by variable new trend of downloadable mobile apps encourages people to shop online. The other variables too aid customers to go for online shopping. Many online companies now offer rating systems that evaluate recommenders in terms of how credible they have been across a number of product recommendations and over time. These rating systems have become popular on online retail sites such as Amazon.com, where consumers can provide ratings (one to five stars) along with an explanation of their rating. Consumers prefer peer and editorial recommendations over other types of effort-reducing cues that might be available during online search. As such, retailers must consider a number of factors including recommender characteristics, shopping goals, and product characteristics in their bid to provide consumers with the appropriate type of recommendation for their respective decision-making task (Smith, Menon, \& Sivakumar, 2005).

Table 5. Statistics of factor E-Retailing Aiders (EA)

\begin{tabular}{lllllllll}
\hline E-Retailing Aiders (EA): & N & Range & Minimum & Maximum & Sum & Mean & Std. Deviation & Variance \\
\hline Peer colleague recommendation & 460 & 4 & 1 & 5 & 1749 & 3.80 & 1.011 & 1.022 \\
New trend & 460 & 4 & 1 & 5 & $\mathbf{1 8 7 7}$ & 4.08 & .934 & .872 \\
$\begin{array}{l}\text { Strict complaint addressing system for online } \\
\text { purchases }\end{array}$ & 460 & 4 & 1 & 5 & 1807 & 3.93 & .927 & .860 \\
Enjoyment in earlier Dollar & 459 & 4 & 1 & 5 & 1597 & 3.48 & .967 & .936 \\
\hline
\end{tabular}


It is seen that consumers who purchased online were more likely to complain online than those who made their purchase offline. Online complaining among online purchasers increased with the degree of dissatisfaction. Complaint channel choice depends on whether the purchase was made in an online or an offline environment. If online, consumers who experienced strong dissatisfaction were more likely to choose online channels for their complaints than those consumers who also made a purchase online but were less dissatisfied (Lee \& Cude, 2011). E-Retailers should take maximum advantages of these aiders to compete against Brick and Mortar outlets.

\subsubsection{E-Retailing Traitors (ET)}

The E-Retailing Traitors (ET) is given nomenclature as all variables in this factor are against E-Shopping. The factor is led by variable mall preference leads to physical shopping, followed by higher ego related needs lead to physical shopping and social pressure leads to physical shopping. In order to compete against physical malls online shopping malls must stress the intrinsic attributes of products to attract highly-involved consumers and must present a benevolent corporate image for consumers concerned with better service. Our results also demonstrated that, for less-involved consumers who wish to search for products to present, it may be appropriate to mix entertainment components with product information, and also to implement creative web interface designs for more effective browsing.

Table 6. Statistics of factor E-Retailing Traitors (ET)

\begin{tabular}{|c|c|c|c|c|c|c|c|c|}
\hline \multicolumn{9}{|l|}{ E-Retailing Traitors (ET): } \\
\hline & $\mathrm{N}$ & Range & Minimum & Maximum & Sum & Mean & Std. Deviation & Variance \\
\hline Higher ego related needs & 460 & 4 & 1 & 5 & 1532 & 3.33 & 1.147 & 1.315 \\
\hline Mall preference leads to physical & 459 & 4 & 1 & 5 & 1769 & 3.85 & .954 & .911 \\
\hline Social pressure leads to physical shopping & 459 & 4 & 1 & 5 & 1483 & 3.23 & 1.195 & 1.427 \\
\hline
\end{tabular}

Shoppers in urban areas are concerned with the logistics, accessibility, ergonomics, and ambiance of shopping malls, which influence their shopping behavior. Research shows that low price, better quality, and availability of a variety of routes to shopping also influence shoppers' behavior in urban markets. Hence, shopping malls and large retailers located in malls normally strive to achieve operating efficiencies by making malls attractive, lowering prices, and opening multichannel retailing options to customers. Such strategies normally enable retailing firms to sustain increasing competition and gain a larger market share. A categorically planned assortment of stores in a mall provides diversity, arousal, and propensity to shop around the mall. Mall managers thus develop appropriate tenancy policies for retailing firms regarding the sociodemographic factors of customers to satisfy different segments (Rajagopal, 2008).

In countries like Gulf where per capita income is very high higher ego related need also drives choice between E-Retailing and physical retailing. The ability to quantify the amount of perceived risk reduction that is needed before the Internet becomes a viable shopping medium. Bhatnagar, Misra, \& Rao (2000) for buyers with higher Ego Needs drifting them to physical stores. 


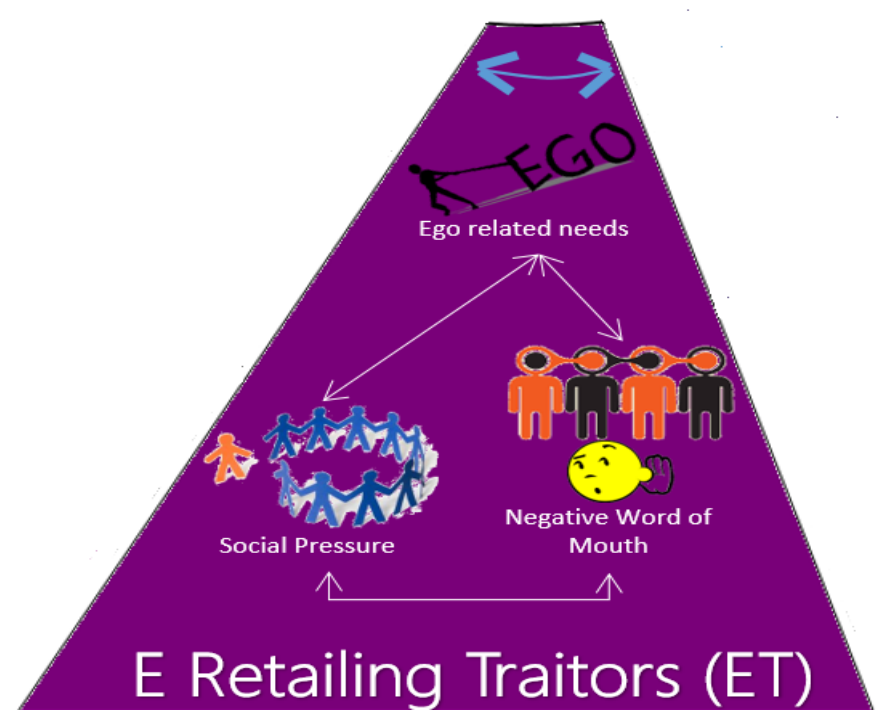

Figure 5. E-Retailing Traitors (ET)

The utilitarian as well as the hedonic values have a significant impact on affect, and indirectly also on e-commerce behavior. Research shows, online shoppers' habitual behavior has a significant impact on affect. Further normative beliefs (social factors) are the preceding factor of habit in cases in which the shopping experience is not recurrent (Pahnila \& Warsta, 2010). Research in Saudi Arab (Member country of GCC) suggests that online strategies cannot ignore either the direct or indirect behavior differences of continuance intentions. Some products in GCC are more convenient to be bought in traditional shopping, whereas others, such as music, software, flight tickets and hotel reservations are easier to buy online. Perceived usefulness, enjoyment, and social pressure are determinants of online shopping continuance in Saudi Arabia. Both male and female groups are equivalent. There are few differences between men's and women's e-shopping behavior, the findings for women are important because of the special role that e-shopping can play in Muslim countries, including Saudi Arabia where there are cultural and legal restrictions on women's activities such as driving (Talal \& Dennis, 2011) Few cultural restrictions are there in other GCC member countries also.

\subsubsection{E-Retailing Modernizers (EM)}

This factor E-Retailing Modernizers (EM) has variables the burst of social networking would encourage E-Retailing among its users, Multimedia $\mathrm{S} / \mathrm{W}$, (that makes product demonstration, attributes \& characteristics look better) would encourage E-Retailing for Non E-Retail buyers, Post purchase experiences lead to higher repurchase online, Store/Brand Loyalty leads to physical shopping.

These variables are real contributors to E-Retailing. Thanks to technology and continuous development in E-Commerce sector, these variables have made E-Retailing easy, useful and boon for consumers. It is argued that social networking, particularly Facebook, is becoming ever more prevalent, particularly with young people. It was originally believed that there is little interest in Facebook shopping in particular and social e-shopping in general, yet it emerged from the research that they often need only a slight 'nudge'. This is apparent, first, because they trust their friends and Facebook is their main way of obtaining information from friends. Searching via Google is understandably the main means of searching for information, yet because information from friends is trusted more, then they often buy on the basis of friends' recommendations, without realizing that they are participating in social e-shop. There is a hierarchy of trust in recommenders/ reviewers from "real" friends at the top down an ordinal scale to reviews on retailers' websites at the bottom. It is believed that this scale should act as a proxy for trust in the recommendations and be positively associated with intention to purchase the recommended product or service (Harris \& Dennis, 2011). 
Table 7. Statistics of factor E-Retailing Modernizers (EM)

\begin{tabular}{lllllllll}
\hline E-Retailing Modernizers (EM): & N & Range & Minimum & Maximum & Sum & Mean & Std. Deviation & Variance \\
\hline The burst of social networking & 460 & 4 & 1 & 5 & 1785 & 3.88 & .964 & .929 \\
Multimedia SW that makes product & 460 & 4 & 1 & 5 & 1708 & 3.71 & .984 & .968 \\
Post purchase experiences & 460 & 4 & 1 & 5 & 1781 & 3.87 & .998 & .997 \\
Store Brand Loyalty leads to physical shopping & 460 & 4 & 1 & 5 & 1772 & 3.85 & 1.025 & 1.050 \\
\hline
\end{tabular}

It is seen that the users of an Internet shopping mall consider the website not merely as an information system but also as a virtual store which provides the full stages of purchasing process of finding, ordering, and receiving using multimedia software. The dual nature of the online consumer as a tradition shopper and a web user implies that the offline features are just as important to retain customers as online quality factors.

Post purchase experience and satisfaction further lead to repeat purchase. Research suggests exploratory information seeking and impulse buying are affected by personal traits, specifically, the consumer trait of hedonic shopping motivation. Further, it is suggested that exploratory information seeking is positively related to pre-purchase browsing time, and subsequently, pre-purchase browsing time is related to online buying frequency. On the other hand, the research also shows that, unexpectedly, pre-purchase and post-purchase online communications are not affected by hedonic shopping motivation (Kim \& Eastin, 2011). The store or brand loyalty though supports more of physical retailing, but most of retails outlets and brands have huge presence on internet through their web sites and customers find it easy to find information through these sites to do comparison and take decisions. Thus it is seen that their online presence definitely a step towards modernizing the E-Retailing.

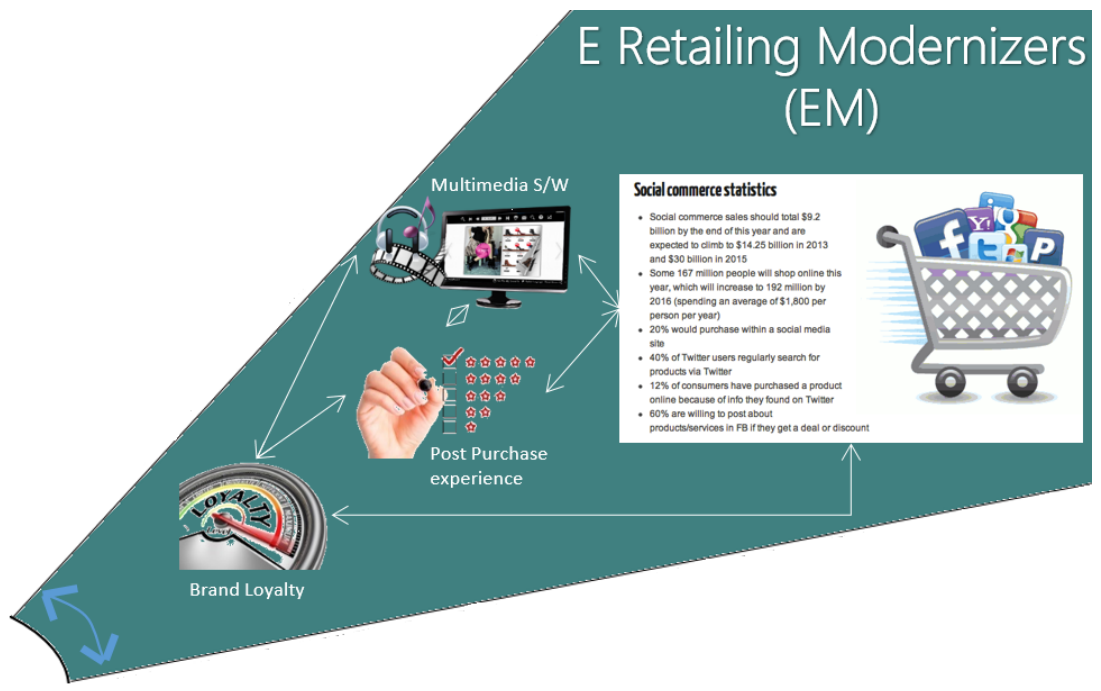

Figure 6. E-Retailing Modernizers (EM)

The technology is further adding feathers to E-Retailing as preferred mode of shopping and all variables under E-Retailing Modernizers factor are pointing the facts as mentioned above.

\subsubsection{E-Retailing Impactors (EI)}

This factor named as E-Retailing Impactors (EI) has variables Online shopping is independent of reputed online retailer brands/product authorized retailer websites, International rating of online shopping site can increase online retailing, and Expert/Celebrity endorsements of online shopping can positively impact it. The factor is led by international rating of online followed by expert celebrity endorsements. In fact, in order to encourage common man for buying online specially for the purpose of sustainability as well as for boosting sales, E-Retailers are heavily using Expert/Celebrity endorsement. Research results show that Singaporean consumers with a higher degree of risk aversion than others tend to perceive Internet shopping to be a risky activity. However, Internet marketers normally rely on using reference group appeal as the most preferred risk relievers for this group of consumers, particularly by getting expert users to endorse the products involved. In addition, 
the marketer's reputation, the brand's image, and specific warranty strategies are also effective risk relievers for the potential Internet shoppers.

The trend is not different in GCC and specially in UAE, where majority of expatriate come to save money to support their family back home in their respective countries. Normally consumers perceive Internet shopping to be of higher risk than in-store shopping; hence only less risk averse consumers are more likely to use Internet shopping services. The high importance placed by the consumers on reference group appeals as an effective risk reliever tool and gives Internet marketers a great opportunity to incorporate reference group in their advertising and promotional strategies in Internet marketing (Soo, 1999).

Investigation shows shoppers' perceptions and use of comparison-shopping sites in general is prevalent and gaining importance. There are many types of shopping comparison sites offering different combinations of information and services. Researcher thinks that measuring likelihood to continue using a comparison shopping site can be tricky issue. Online-rating sites are continuing evolving. Some of these sites are adding qualitative shopper reviews/feedback on products and merchants. Consequently, a search results page may contain a mixed listing of merchants carrying a particular product along with their ratings, and of brand models along with shopper feedbacks on the brand or model.

The utility and market values of shopping comparison sites have attracted Internet giants such as eBay, Google, and Yahoo to the extent of developing or acquiring such sites. Scholarly research on comparison-shopping sites has focused on trust in online recommendation agents, and methods used by electronic agents to produce the recommendations. Research further dispelled the notion that e-retailers presented by shopping comparison sites need to compete, basically, only on price. Consumers perceived shopping comparison sites to be moderately trustworthy and useful. The effect of interactivity of a website is salient in the existence of a strong trust in the retailer. When consumers have a low level of trust in the retail brand, their perceiving the website as interactive and innovative may not necessarily translate into shopping at the site; however, when they highly trust the retail brand, the more positive they perceive the website to be in terms of those aspects, the more likely they are to shop from the site (Ong, 2011).

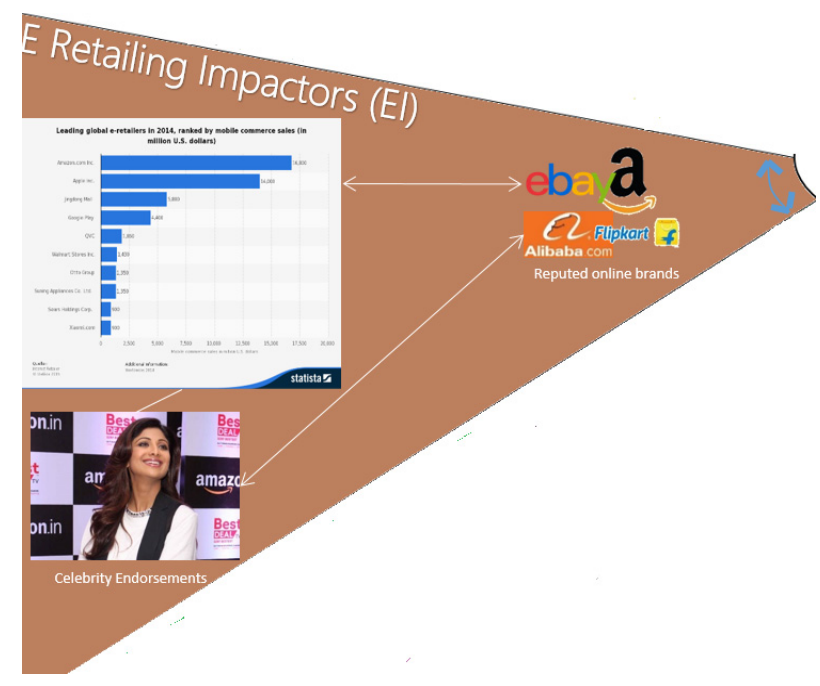

Figure 7. E-Retailing Impactors (EI)

Table 8. Showing statistics of factor E-Retailing Impactors (EI)

\begin{tabular}{lllllllll}
\hline E-Retailing Impactors (EI): & N & Range & Minimum & Maximum & Sum & Mean & Std. Deviation & Variance \\
\hline Expert Celebrity endorsements & 460 & 4 & 1 & 5 & 1714 & 3.73 & 1.051 & 1.106 \\
Online shopping is independent of reputed online & 460 & 4 & 1 & 5 & 1620 & 3.52 & 1.026 & 1.052 \\
International rating of online & 460 & 4 & 1 & 5 & 1805 & 3.92 & .915 & .837 \\
\hline
\end{tabular}

It is normally believed Consumers with a higher level of offline trust in a retail brand perceived the retailer's website more favorably than others and they also more strongly intended to purchase from the site. However, 
research shows offline brand trust perhaps exerts a halo effect and that when individuals have a strong trust in a retailer, their consideration of the internet as an efficient tool does not make as strong an effect on their perception of the usability of the retailer's website as it does for individuals lacking in brand trust. Perceiving the internet as an efficient tool predicted a positive perception of usability and information quality of a website more strongly when the respondent had a lower degree of trust in the retailer, the effect of interactivity of a website is salient in the existence of a strong trust in the retailer. When consumers have a low level of trust in the retail brand, their perceiving the website as interactive and innovative may not necessarily translate into shopping at the site; however, when they highly trust the retail brand, the more positive they perceive the website to be in terms of those aspects, the more likely they are to shop from the site (Kim \& Jones, 2009).

All in all, E-Retailing Impactors are really impacting buyers to have faith and do online shopping with faith.

\subsubsection{E-Retailing Limiters (EL)}

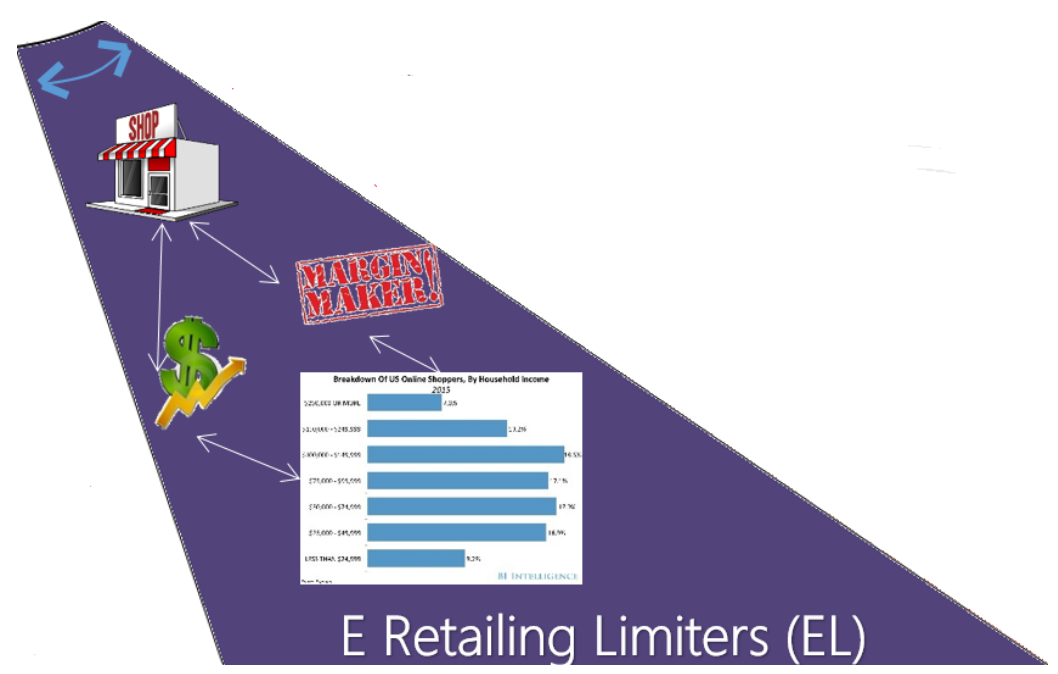

Figure 8. E-Retailing Limiters (EL)

This factor named as E-Retailing Limiters (EL) has variables Concept of Mega Malls (which have multiple high end retail channels catering lifestyle of local society, attractiveness of malls, shopping incentive) discourages online retailing, to seek better margin, organizations are encouraged to physically retail their specific higher margin model themselves rather through E-Retailing and there is correlation between Per Capita Income \& shopping online. The factor is led by variable to seek better margin organizations are encouraged to physically retail their specific higher margin model themselves rather through E-Retailing.

Hospitality is a big contributor to UAE specially Dubai economy. It has transformed itself as Malaysia of Asia. Today it attracts more than fifty million tourists annually. Dubai national airlines have enhanced its capability along with infrastructure of UAE to boost hospitality, retail and trading which are helping achieve mile stones for UAE. It has been seen that unique and mega malls create huge tourist attraction, so managers of shopping malls and retailing firms should understand customer reaction to economic and relational factors that determine their perceptions and attitude toward shopping in an urban retail setting.

Table 9. Statistics of factor E-Retailing Limiters (EL)

\begin{tabular}{lllllllll}
\hline E-Retailing Limiters (EL): & \multicolumn{10}{c}{} \\
\hline Concept of Mega Malls & N & Range & Minimum & Maximum & Sum & Mean & Std. Deviation Variance \\
There is correlation between Per & 460 & 4 & 1 & 5 & 1658 & 3.60 & 1.056 & 1.115 \\
To seek better margin & 460 & 4 & 1 & 5 & 1605 & 3.49 & .955 & .913 \\
& 460 & 4 & 1 & 5 & 1665 & 3.62 & .952 & .907 \\
\hline
\end{tabular}

A categorically planned assortment of stores in a mall would provide diversity, arousal, and propensity to shop around the mall. Accordingly, mall managers may develop appropriate tenancy policies for retailing firms regarding the sociodemographic factors of customers to satisfy different segments. Shoppers in urban areas are 
concerned with the logistics, accessibility, ergonomics, and ambiance of shopping malls, which influence their shopping behavior. Results show that low price, better quality, and availability of a variety of routes to shopping also influence shoppers' behavior in urban markets. Hence, shopping malls and large retailers located in malls should strive to achieve operating efficiencies by making malls attractive, lowering prices, and opening multichannel retailing options to customers. Such strategies would enable retailing firms to sustain increasing competition and gain a larger market share. Researcher believes and as supported by data that, because of high per capita income, many retailers make their certain high margin models with slight ID difference, directly available only at physical stores. In fact, making such move is in sync with both the variables.

\subsubsection{E-Retailing Discretors (ED)}

This factor named as E-Retailing Discretors (ED) has variables majority of expatriates, who live alone and face loneliness \& perceived social support are more likely to use internet and shop online, Privacy concern is one of the reasons to go for online shopping (Products you may not like to buy in public).

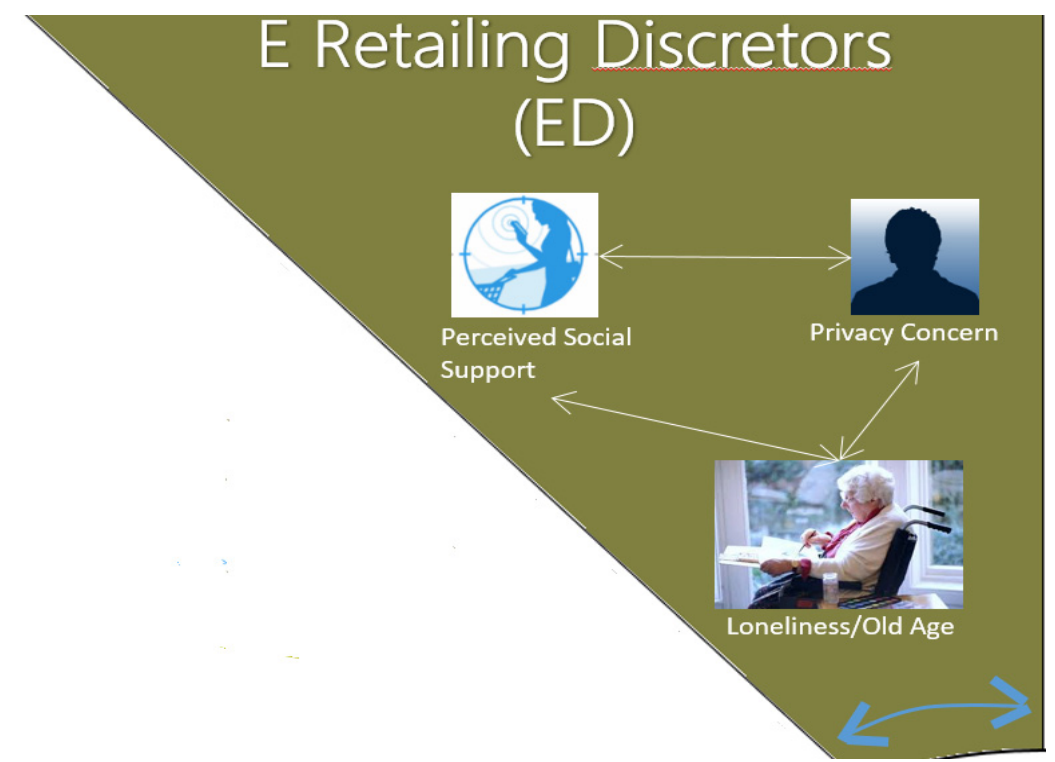

Figure 9. E-Retailing Discretors (ED)

In E-Retailing Products and type of services influence the relationships between consumer characteristics and attitudes toward online shopping. Consumer characteristics are found to influence online shopping acceptance. However, relationships were affected by different product types. Increased personal privacy concerns negatively affect user attitudes toward purchasing tangible or physical products or services. Personal innovativeness of information technology, perceived Web security, personal privacy concerns, and product involvement can influence consumer acceptance of online shopping, but their influence varies according to product types (Lian \& Lin, 2007). Since consumer characteristics are found to influence online shopping acceptance. When designing a marketing plan, online retailers must consider two key questions. The first question involves the identity of potential buyers.

Table 10. Statistics of factor E-Retailing Discretors (ED)

\begin{tabular}{|c|c|c|c|c|c|c|c|c|}
\hline \multicolumn{9}{|l|}{ E-Retailing Discretors (ED): } \\
\hline & $\mathrm{N}$ & Range & Minimum & Maximum & Sum & Mean & Std. Deviation & Variance \\
\hline Online shopping is virtue for old age last & 460 & 4 & 1 & 5 & 1647 & 3.58 & 1.192 & 1.421 \\
\hline Privacy concern is one of the reasons to go & 460 & 4 & 1 & 5 & 1519 & 3.30 & 1.220 & 1.488 \\
\hline
\end{tabular}

The above mentioned variables are nomenclature as discretors as data did not support much on these two variables. In country like UAE where cultural is bit different privacy concern plays important role for E-Retailers Further overall security is good here so old aged people and loneliness which may lead to E-Retailing. Majority of old aged people are locals (Nationals of UAE), who are supported well by government through social welfare 
thus, this variable too has low impact on E-Retailing.

\subsection{Shaping the Relational Direction Model (RDM) of E-Retailing}

After analyzing all the factors two discrete set of sectors/sections were made and given special name as E-Retailing fraternity and Brick \& Mortar fraternity. These two sectors/sections are putting pressure on each other for customers to go for E-Retailing and/or Brick and Mortar shopping. In place like UAE Brick and Mortar fraternity is equally strong for the reasons mentioned as factors (containing number of variables) which have been explained and mentioned above. Researcher finds that government compulsion for fiscal and revenue is encouraging E-Commerce which improves GDP and the standard of living of locals.
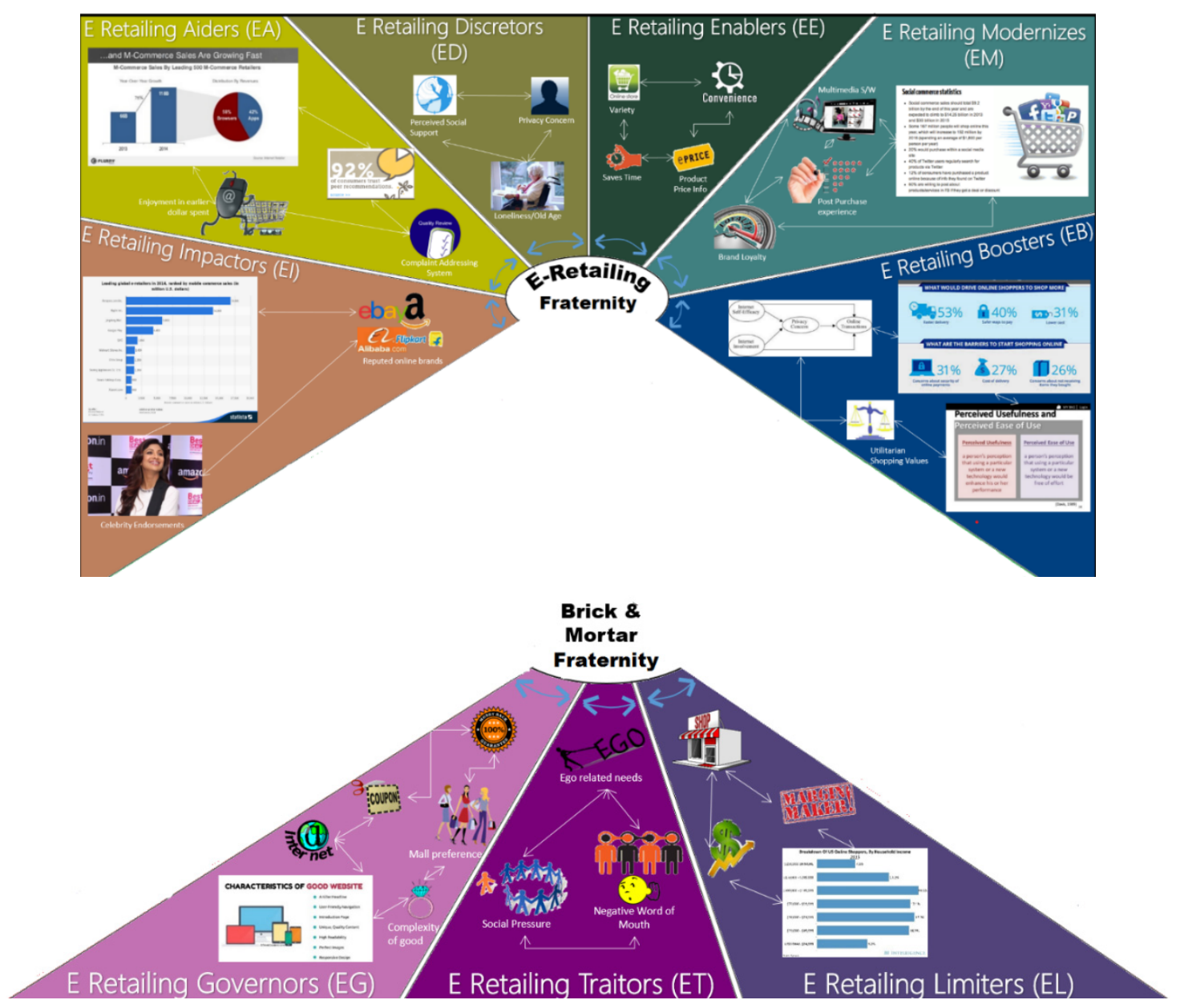

Figure 10. E-Retailing fraternity and Brick \& Mortar fraternity

When above two sectors/sections are combined the result would be a model which is giving the relational direction. The relational word explains the dependence, interconnectivity and influence of each of variable within factor and influence of each factor on each other within same fraternity and other fraternity. For GCC Countries and UAE in particular Retailers have to focus more on variables and factors coming under E-Retailing Fraternity and moderately take care of Brick and Mortar Fraternity. The complete model is as follows: 


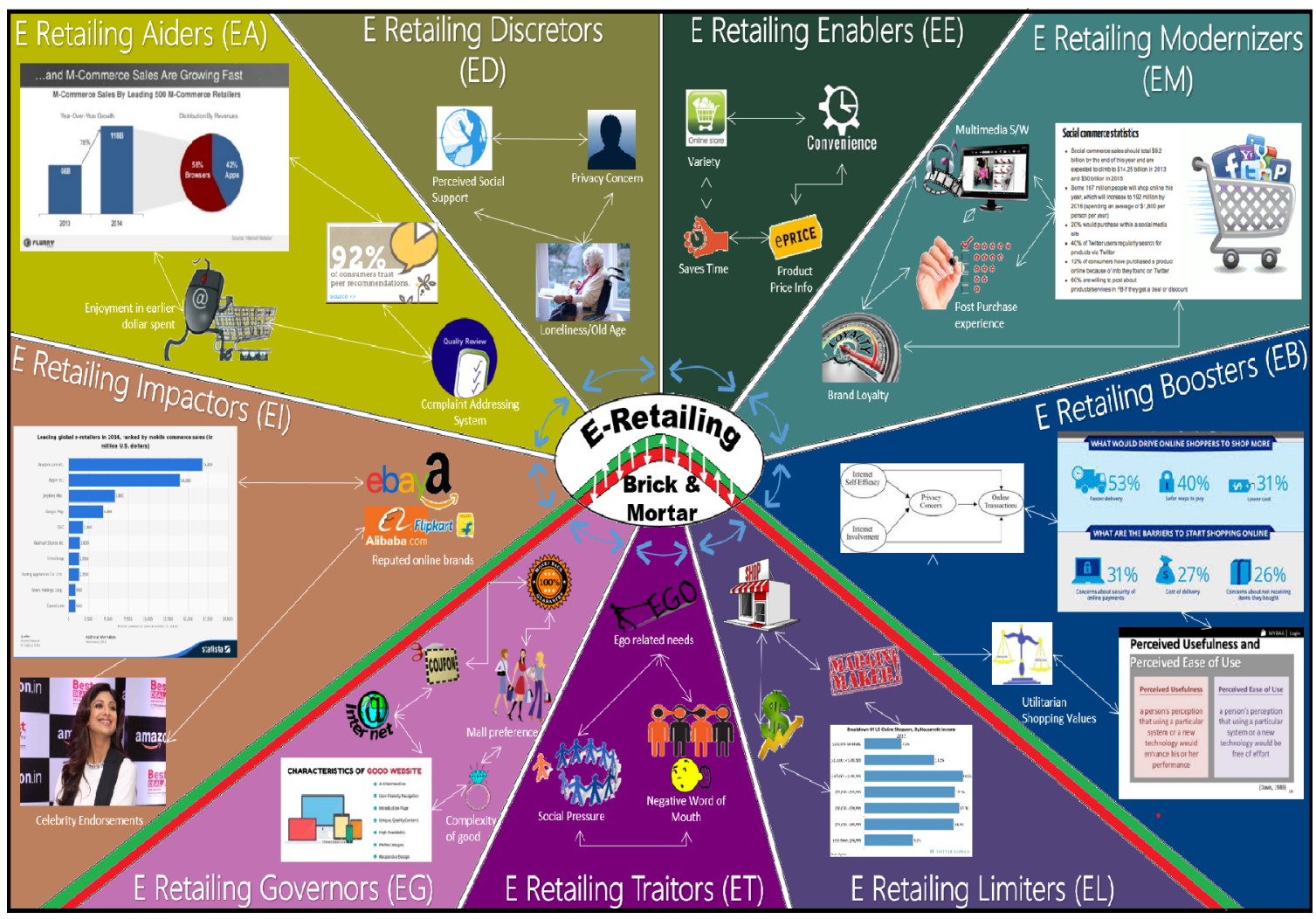

Figure 11. The complete model

\section{Recommendations}

\subsection{Recommendations for Corporate}

UAE has always taken lead in establishing many innovative measures and decisions. Setting up international rating agency for E-Commerce and E-Retailing would take country to newer heights in both E-Commerce and E-Retailing. It is worth mentioning that E-Retailing worldwide has crossed mark of $\$ 1.5$ trillion (with growth over 20\%) in 2015 and in 2016 it expected to touch $\$ 2.0$ Trillion mark. UAE traditionally is strong in Trading so such initiative of Setting up international rating agency would overall impact physical trading which in turn would impact GDP as UAE is cross over between east and west.

In order to further boost E-Retail UAE, need to encourage marketers to establish .ae for business as domains. This would get UAE extra millage in E-Retailing and would impose faith trading community has in UAE.

UAE government needs to establish strong online consumer complaint system so that buyers would have more faith in retailing online. Worldwide such initiatives have been lauded and many countries have benefited from them.

Respondents accepted new way of retailing, by responding to question as how is their attitude to accept change towards online retailing; $77 \%$ responded as comfortable. Further points finger that it is high time for marketers to start working towards offering their products and services through E-Retailing and gear their infrastructure and customer service initiatives supporting E-Retailing.

Marketers in UAE need to encourage people for download apps as such initiatives have paid worldwide in E-Retail business.

Marketers need to develop good transaction services (security, product guarantees, safety of information, privacy, and delivery/customer service) as it leads to online shopping. This factor has always dominated E-Retailing fraternity and would benefit E-Retailers in UAE too.

E-Retailing is encouraged by website characteristics (like design, multiple contact points alternative ordering, good product search \& comparison matrix, the number of monthly \& quarterly changes, and accessibility from other web pages). Better are the characteristics more it encourages people to go for E-Retailing. Better, reliable 
and attractive characteristics of established E-Retailers are confirmatory test to this fact. It is worth noting that in UAE too margins, are under pressure as it is worldwide in most other businesses, so better website characterstiucs always contribute to improve the bottam line of the E-Retailers through efficiency and reduced supply chain cost.

Guaranteed money refund (on return) of purchased product impacts online shopping positively. Over a period of time E-Retailers have started emphasizing on this through their integrated marketing communication. The emerging markets are using this tool to encourage non-users of E-Retailing to switch to E-Retailing. Retailers in UAE too have to offer this facility so that custormers would have faith in E-Retailing.

International rating of online shopping site can increase online retailing. Such service presently is not available at international level, however, an emerging economy of India has such service available through Department of Consumer Affairs National Informatics Centre which is Govt. of India Enterprise. Data consensus among respondents affirms that this factor needs to be developed and encouraged by retailers. UAE needs to take initiative to such agency to give direction and boost to E-Retailing.

Social networking would encourage E-Retailing among its users as one important factor. Reacher feels this factor has contributed to large extent E-Retailing in UAE. Government should not put any kind of restriction on such sites of course without compromising on security and sovereignty of the country.

Marketers should make note that Expert and Celebrity endorsement has always been heavily used by marketers and their respective advertising agencies to influence prospective shopper. In case of E-Retailing Expert/Celebrity endorsements of online shopping too can positively impact it.

Multimedia S/W, (that makes product demonstration, attributes \& characteristics look better) and comparison with competitor's feature would encourage E-Retailing for Non E-Retail buyers.

Marketers to further focus on Utilitarian (Useful/Practical) Shopping values which leads to Online Shopping. The current size of market, its annualized growth and the way preference is shifting to E-Retailing mode of shopping shows referred factor as one of the important factor for its liking by shoppers.

Respondents accepted new way of retailing i.e. E-Retailing, by responding to question as how is their attitude to accept change towards online retailing; $77 \%$ responded as comfortable, $7.8 \%$ felt uncomfortable and $15.2 \%$ declined on commenting on this question shows marketers should put all efforts to take advantage of this swing.

To the question on Provider of Most Comprehensive E-Retail Experience 36.74\% opted for Internet only retailers, followed by $29.13 \%$ Traditional Retailer website, $24.13 \%$ opted for Manufacturer Web pages and least $9.53 \%$ opted for used sales/purchase item retailer. The above shows faith buyers have in E-Retailing.

If E-shopping for first time your behavior as shopper is $37.17 \%$ opted for Protective Behavior, $33.26 \%$ adaptive. The overall responses together are a good indicator of acceptability of E-Retailing by people of UAE. Now it is up to marketers to use this factor to action.

Variety of items currently bought by people online (Electronics and Home Appliances 56.30\% Travel Ticket \& Tourism related Services 55.00\% Cloths \& Garments 48.91\% Gaming Consoles, Accessories \& Games 29.78\% Books, Magazines \& Newspapers 28.04\% Watches \& Jewelry 27.60\% Kitchen Items $24.56 \%$ ICT and Mobile Phones 21.30\% Leather Products 21.08\% Personal Care Products 19.78\% Sports Goods 16.52\% FMCG 13.91\% Furniture and Upholstery $10.21 \%$ Toys $10.00 \%$ Big Boy Toys 9.34\%) shows people have faith in every type of product so marketers from each sector/industry should put more impetus to E-Retailing their respective product and service offerings

\subsection{Recommendations for Future Researchers}

In online retailing as in any retailing business it must not be forgotten that elements of the integrated marketing communication tools are required in order to attract, retain and maintain customers. Marketers need to look into E-Retailing fraternity as mentioned in model. Further research can be undertaken to comprehensively find communication correlation ship between integrated marketing tools and E-Retailing.

No research is comprehensive and further research can bring more insight into slow yet developing online retail in UAE.

The Relational Direction Model (RDM) of E-Retailing developed by researcher emphasis that marketers should focus on Sector/sections 1 (Upper half of model) factors like known as E-Retailing Fraternity E-Retailing Enablers (EE), E-Retailing Boosters (EB), E-Retailing Aiders (EA), E-Retailing Modernizers (EM), E-Retailing Impactors (EI) E-Retailing Discretors (ED). All the variables in these factors would lead UAE to E-Retailing. Further research on this model can bring insight into factors mentioned in the model, their relationship and 
further insight if any on validity of this model.

\section{References}

Al-Maghrabi, T., \& Dennis, C. (2011). What drives consumers' continuance intention to e-shopping? Conceptual framework and managerial implications in the case of Saudi Arabia. International Journal of Retail \& Distribution Management, 39(12), 899-926. http://dx.doi.org/10.1108/09590551111183308

Cockburn, C., \& Wilson, T. D. (1996). Business Use of the World Wide Web. International Journal of Information Management, 16(2), 83-102. http://dx.doi.org/10.1016/0268-4012(95)00071-2

Dholakia, U. M., \& Rego, L. L. (1998). What makes commercial Web pages popular? European Journal of Marketing, 32(7), 724-736. http://dx.doi.org/10.1108/03090569810224119

Emad, Y. M. (2013). The Effect of Perceived Risk on Online Shopping in Jordan. European Journal of Business and Management, 5(6).

Jang, Y. T. J., Chang, S. E., \& Chen, P. A. (2015). Exploring social networking sites for facilitating multi-channel retailing. Multimedia Tools and Applications, 74(1), 159-178. http://dx.doi.org/10.1007/s11042-013-1430-z

Kim, E. Y., \& Kim, Y. K. (2004). Predicting online purchase intentions for clothing products. European Journal of Marketing, 38(7), 883-897. http://dx.doi.org/10.1108/03090560410539302

Legoherel, P., Fischer-Lokou, J., \& Gueguen, N. (2000). Selling Tourism on the Internet: Analysis of the Balance of Power Between Seller and Consumer During Information Exchange and Negotiation. Journal of Travel \& Tourism Marketing, 9(3), 49-64. http://dx.doi.org/10.1300/J073v09n03_04

Ong, B. S. (2011). Online Shoppers' Perceptions and Use of Comparison-Shopping Sites: An Exploratory Study. Journal of Promotion Management, 17(2), 207-227. http://dx.doi.org/10.1080/10496491.2011.553789

Pappas, I. O., Kourouthanassis, P. E., Giannakos, M. N., \& Chrissikopoulos, V. (2014). Shiny happy people buying: the role of emotions on personalized e-shopping. Electronic Markets, 24(3), 193-206. http://dx.doi.org/10.1007/s12525-014-0153-y

Srivastava, R. K. (2008). Changing retail scene in India. International Journal of Retail \& Distribution Management, 36(9), 714-721. http://dx.doi.org/10.1108/09590550810890957

White, G. K., \& Manning, B. J. (1998). Commercial WWW site appeal: how does it affect online food and drink consumers' purchasing behavior? Internet Research: Electronic Networking Applications and Policy, 8(1), 32-38. http://dx.doi.org/10.1108/10662249810368860

Yeh, J. C., Hsiao, K. L., \& Yang, W. N. (2012). A study of purchasing behavior in Taiwan's online auction websites: Effects of uncertainty and gender differences. Internet Research, 22(1), 98-115. http://dx.doi.org/10.1108/10662241211199988

\section{Copyrights}

Copyright for this article is retained by the author, with first publication rights granted to the journal.

This is an open-access article distributed under the terms and conditions of the Creative Commons Attribution license (http://creativecommons.org/licenses/by/4.0/). 